\title{
The American Interest in Islamic Schooling: A Misplaced Emphasis?
}

\section{Gregory Starrett}

\author{
Dr. Starrett is associate professor in the Department of Anthropology at \\ the University of North Carolina, Charlotte. This essay is a revised version \\ of a paper presented at a workshop on Islam in Middle Eastern School \\ Textbooks: Nation-Building, Identity, and the Question of Reform, sponsored \\ by the United States Institute of Peace (March 23, 2004), and a conference \\ on Koranic Schools in the Middle East, Pakistan and Africa, sponsored by \\ the U.S. State Department and the National Intelligence Council \\ (September27, 2004).
}

I n his recent book Our Posthuman Future, Francis Fukuyama argues that advances in genetic engineering, neuroscience and psychopharmacology threaten us with frightening new potentials for physical and mental control that might undermine the very free will and rational judgment necessary to the emergence and strengthening of democratic systems of government. As grim as this prospect is (think of the recent remake of The Manchurian Candidate, in which a neural implant replaces the more laborintensive process of brainwashing), the mechanisms of such control have struck many readers as less likely than its intent. In a review of Fukuyama's book in the New York Review of Books, prominent evolutionary biologist Richard Lewontin dismissed the argument, scoffing that "The remaking of human history by the technological manipulation of the human nervous system belongs to the literature of science (C) 2006, The Author fiction. ... When it comes to having the power to make history Fukuyama can have the neuropharmacology laboratories. I'll take the madrasas."

Madrasa. The very word can send a shudder up the post-9/11 spine, as these Islamic religious schools - purportedly the training grounds for Islamist militants in places like Pakistan and Saudi Arabia have become part of the American vocabulary. As Lewontin demonstrates, "madrasa" has become an index of threat so clear that it requires no translation for the reader of a book review concerning recent work in the history of science. American concern about madrasas stretches back at least as far at the summer of 2000, when journalist Jeffrey Goldberg published a feature article, "The Education of a Holy Warrior," in The New York Times Magazine. ${ }^{2}$ The article concerned the Haqqania madrasa (labeled "Jihad U." by the editors) in the Northwest Journal Compilation (C) 2005, Middle East Policy Council 
Frontier Province of Pakistan, which had provided young soldiers for the support of the Taliban victory in Afghanistan. A shorter version of the article was published in the first post-9/11 issue of Rolling Stone, ${ }^{3}$ reaching a broader audience nationwide. Not to be outdone, on November 15, 2001, Thomas Friedman reported on his own visit to Jihad U., in one of the columns that helped him earn a Pulitzer Prize for commentary the following April:

[Pakistan] is bin Laden land. This is not a region where America is going to sink any friendly roots. In part it's because the Pashtuns here all. . side with their brothers in Afghanistan; in part it's because they were jilted once before by the Americans [who] dropped Pakistan like a used hanky once the Soviets left Afghanistan. But, most important, it's because of the education system here.

On the way in to Peshawar I stopped to visit the Darul Uloom Haqqania, the biggest madrasa. . .in Pakistan, with 2,800 live-in students - all studying the Quran and teachings of the Prophet Muhammad with the hope of becoming mullahs, or spiritual leaders. I was allowed to sit in on a class with young boys, who sat on the floor, practicing their rote learning of the Quran from holy texts perched on wooden holders. This was the core of their studies. Most will never be exposed to critical thinking or modern subjects. ...

Bin Laden is a sideshow, but one we must deal with. The real war for peace in this region. . .is in the schools. Which is why we must do our military operation against bin Laden quickly and then get out of here.

When we return, and we must, we have to be armed with modern books and schools - not tanks. Only then might we develop a new soil - a new generation as hospitable to our policies as to our burgers.

Until then, nothing pro-American will grow here.

Anti-American sentiment in the Middle East and the broader Muslim world is unsettling. The much-quoted Pew Research Center Global Attitudes Project reported in March 2004 that 61 percent of Pakistanis, 63 percent of Turks and 68 percent of Moroccans had unfavorable opinions of the United States. But focusing on Islamic education as a primary cause of anti-American sentiment, global terrorism or other forms of violence does a disservice to our understanding of the challenges we face in this new century. Such a focus doesn't explain why unfavorable opinion of our country in France and Germany (62 percent and 59 percent, respectively) is as high as that in many parts of the Middle East. It doesn't explain why the leaders and ideologues of violent Islamist movements almost always have secular higher educations rather than the blinkered backgrounds of Friedman and Goldberg's madrasa boys. ${ }^{4}$ And it doesn't explain why we choose to see Islamic schooling of any sort as a direct motivator of behavior. After all, we don't blame French and German schools for the views of their citizens. Why do we blame Middle Eastern schools for the views of theirs, particularly when such views are both irregularly distributed and in constant flux? The Pew survey project found in May 2003 that more than twice as many Moroccans as Germans held "very favorable" views of the United States. Can there be more madrasas in Bremen than in Marrakech? 
Middle East Policy, Vol. XIII, No. 1, Spring 2006

I would argue that American fascination with madrasas and other Middle Eastern educational institutions stems less from their actual contribution to terrorism than it does from our commonsense understandings of causality, rationality and the purposes of education. Friedman's faith that socialization is the key to understanding and shaping human culture has a distinguished genealogy. In the 1930s, for example, many anthropologists looked to child-rearing practices to explain not only the adjustment of individuals to their social surroundings, but to explain the nature of cultural difference itself. Each culture, the logic goes, like each person, has a more or less integrated style of life, set of interests, and capacity for perception and expression. In the context of interwar psychology, this insight along with a broader interest in Freudian psychodynamics led to a body of work that attempted to link childrearing practices to adult personality, and thus to the social and cultural forms most congenial to those average, or modal, personality types. Anthropologists and psychologists sought to explain social behaviors by tracing their origins to patterns of infantile interaction with caregivers, so that - to give a well-known example from the postwar period - the development of Russians' attitudes toward external authority, a potent mixture of guilt and rage at constraints that are both hateful and necessary, might be explained by the common practice of infant swaddling.

This approach was eventually discarded for making far too much of the lasting effects of child-rearing practices. But its underlying logic suffuses current political concerns about Quranic schools. Now it is no longer early childhood experi- ence, but school experience, that is targeted as the Very Core of Behavior. They hate us because they teach their children to hate us.

\section{THEY'LL LIKE US WHEN WE WIN}

By early 2002, madrasa-talk had spread from the journalism of Goldberg and Friedman to the field of television drama, where it began to be used without gloss or elaboration as an index of Culture Gone Bad. Here, for example, is fictional White House Communications Director Toby Ziegler from the NBC television show The West Wing (February 6, 2002):
They'll like us when we win! Thou- sands of madrasas teaching children nothing, nothing, nothing but the Quran and to hate America. Who do we see about that? Do I want to preach America? Judeo-Christianity? No. If their religion forbids them from playing the trumpet, so be it. But I want those kids to look at a globe. Be exposed to social sciences, history. Some literature. [Long pause.] They'll like us when we win.

From journalism and fiction the madrasa jumped to policy. In a confidential memo to his senior staff dated October 16, 2003, Secretary of Defense Donald Rumsfeld asked,

Are we capturing, killing or deterring and dissuading more terrorists every day than the madrasas and the radical clerics are recruiting, training and deploying against us? Does the U.S. need to fashion a broad, integrated plan to stop the next generation of terrorists?... How do we stop those who are financing the radical madrasa schools?... Does the CIA need a new 
finding? Should we create a private foundation to entice radical madrasas to a more moderate course?

And, finally, Secretary of State Colin Powell, during a radio interview on January 21,2004:

We have been talking [to] Middle Eastern leaders. . .and made it clear to them that Islam is a great religion. But they also have to be educating their youngsters not just in the tenets of Islam.... [T] hey have to educate [them]....for the demands of the twenty-first century. They've got to give them skills. They've got to teach them to read and write. They've got to teach them science and math and all the other things that are necessary for societies to be successful in the twenty-first century.

And if they're just going to....put [their young people] in these madrasas. ....that do nothing but indoctrinate them in the worst aspects of a religion, then they are....leaving themselves back as well as teaching hatred that will not help us bring peace to the region, and will not help their societies. And we're working on them....in this regard.... We're helping them to learn how to educate youngsters for the twenty-first century.

Is education really the cause of civilizational struggle? Will particular sorts of school curricula generate world peace, and others world war? Should we be concerned, in national security (rather than humanitarian) terms, about "messages of hatred and. . incitements for martyrdom in [Saudi and Palestinian] textbooks and on the media that take young minds and twist and pervert them and create a new gen- eration of terrorists and insurgents," as Senator Hillary Rodham Clinton (D, NY) told the American Israel Public Affairs Committee at the end of May 2005? This is not the first time Westerners have expressed concerns about the political dangers nurtured by inadequate Semitic systems of education. For the sake of historical and comparative perspective, two of these examples, some six centuries apart, can help frame the way we think through these issues today.

\section{CHIEF CAUSE OF THEIR PERFIDY}

On the first Saturday of Lent, March 3, 1240, Dominican friars aided by Jewish converts to Catholicism seized copies of the Talmud and other Jewish books all over Paris on the order of Pope Gregory IX. On June 25, a royal court staged a trial of the books on the charges of blasphemy against God; slander against Jesus, Mary and Christianity; and general foolishness. The complaint had been made that the Talmud was "the chief cause that holds [Jews] in their perfidy." 5 In 1244, Pope Innocent IV criticized the Talmud as a book that "throw[s] away and despise[s] the Law of Moses and the prophets, and follow[s] some tradition of [the Jewish] elders. . . In traditions of this sort they rear and nurture their children," 6 forbidding them even to study their own Bible for fear that their sons would become Christians if they understood the true meaning of the Mosaic teachings. ${ }^{7}$ The books were condemned and 24 cartloads were burned at the stake on Friday, June 6, 1242, an act repeated again in Paris in 1309 and 1321, as well as in Toulouse, Bourge and Pamiers. ${ }^{8}$ Odo, a papal legate involved in the investigation and prosecution of the books, wrote in 1248, "We found that these 
Middle East Policy, Vol. XIII, No. 1, Spring 2006

books were full of innumerable errors, abuses, blasphemies and wickedness such as arouse shame in those who speak of them and horrify the hearer, to such an extent that these books cannot be tolerated in the name of God without injury to the Christian faith.... and we decisively condemn them."

When the Talmud was not burned publicly, it was sometimes ordered - by James I of Aragon, for example — that the Jews expunge whatever the Dominicans took to be blasphemies against Jesus and Mary. ${ }^{10}$ Gregory's successor, Innocent IV, the first Pope to refer to himself as the Vicar of Christ, presided over an unprecedented extension of the legal authority of the Apostolic See. Not only was the Bishop of Rome responsible for the moral welfare of Christians, but of the Jewish community as well. He insisted that Jews follow the law of Moses without elaboration or addition, ensuring thus "the purity of Jewish doctrine and its conformity to the teachings of the Old Testament"11 and protecting them from heresies within their own tradition. ${ }^{12}$ He had become in effect "the overseer of the rabbinate."13 The Church was helped in this not only by converts, but by Karaites and by other Jews who condemned Maimonides. "You are destroying your heretics," wrote Solomon ben Abraham to the Dominicans of Montpellier (ca. 1232), "help us to destroy our heretics." 14

None of this is to suggest any equivalence between the forgettable contemporary school curricula of the Middle East and the works of Maimonides. It is merely to heighten our awareness of the various motives different parties have in paying attention to, criticizing, condemning and seeking to have rewritten the educational materials of others. These motives are hardly ever centered selflessly on the interests of those others and often turn out to be embarrassing, if not horrifying, in retrospect.

Closer to our own time, the middle of the nineteenth century saw imperial Britain in the Middle East target education as the source of the pervasive "fanaticism and bigotry" it encountered in places like Egypt and Yemen, as local religious scholars and mosque functionaries insisted on treating the Europeans as ritually impure infidels rather than as moral superiors and avatars of enlightenment. Fanaticism and bigotry as mental qualities helped administrators explain the slow pace of economic and political change and the occasional outbreaks of political or religious violence. "The Egyptian," recalled Alfred Milner, the former under-secretary for finance in Egypt, “....is not by nature in the least fanatical. But he has been brought up in fanatical traditions, and he is greatly under the influence of religious teachers, who are fanatics by profession." 15 Describing Quranic education as it existed in the 1830 s, one traveler wrote that religious instruction in Egyptian village and urban schools

turns principally upon the religious observances required by the Quran, and degenerates into extreme frivolity. Rarely is any lesson of morality given, and the passages of the Quran, which teach the cultivation of the virtues, are much less introduced and commented on than those which bear upon the ceremonials of the Mussulman faith. Inquiries as to the quantity of adulteration, which makes water improper for ablution - into the grammatical turn of the language of prayer — into 
the cases in which the obligations to fast may be modified - into the gestures in adoration most acceptable to Allah - into the comparative sanctity of different localities and similar points - are the controversies which are deemed of the highest importance, and the settlement of which is supposed to confer a paramount reputation upon the Ulema. ${ }^{16}$

"[T] he most worthless character" of such pursuits disqualified this sort of education as education at all. Milner fumed that

....continually repeating, in a monotonous chant, a quantity of matter which you are taught to regard with religious reverence, but never taught to understand, is, if anything, an anti-educational process. If the object of true education be intellectual

gymnastic, if it be to exercise and render supple the joints of the mind, then this system is its very opposite, for it tends to stiffen them. It is not calculated to enlighten, but to obfuscate. ${ }^{17}$

Consequently, reformers hoped to revolutionize the teaching of Islam to move beyond rote memorization of text to include explicit instruction in history and morality. In this way, "the Quran might be made, like the Bible, a means of imparting moral truth combined with instructive history. This is not done, the poor little children's nascent powers are warped and stunted, and the results appear when their higher education is attempted." 18

The differences Europeans saw between their own "moral" approach to religion and the merely "ritual" concern of Egyptians formed an important part both of European self-understanding and of their strategic intervention in Egyptian education, religious and otherwise. Offering small monetary subsidies to local Quranic schools in Egyptian villages that agreed to submit to national inspections, and establishing a limited number of modern-style schools to train Egyptians as local technicians and government functionaries, the colonial government sought to manage social and geographic mobility. The language taught in village schools was restricted to Arabic, and enrollment in European-style schools was strictly limited to avoid creating an educated class that could not be absorbed in the bureaucracy. But it was Egyptians who were educated in these modern schools and studied abroad in Europe, who later became leaders of both the secular Egyptian nationalist movement and the modern Islamic movement that helped lead insurrections against foreign mastery of their country. Their work to disrupt British control flowed not from radical cultural differences nurtured at school, but from shared commitments to modernity coupled with vast differences in their practical political interests. It is ironic that our current complaints about Islamic education no longer have to do with its 
Middle East Policy, Vol. XIII, No. 1, Spring 2006

excessive focus on ritual, but rather with its focus on moral truths and instructive histories of which we don't approve. Both then and now, what was meant by truth and instruction is the kind of truth and instruction that accomplishes our own particular goals. Given contemporary concerns about the politicization of Middle Eastern curricula, we might, now, actually wish that religious education had stuck to grammar and purity laws.

Currently the official religious education programs in Egyptian government and private schools carry on the traditions of moral truth combined with instructive history by teaching a vision of Islam that is simultaneously exclusivist and quietist. It is exclusivist in that a generic Islam is portrayed as the only truly legitimate religious tradition. It is a religious tradition, however, that knows no borders of ethnic, class, national or gender difference.

Muslims are different from others not because they are a certain kind of people, but because they have made a certain kind of enlightened choice. The same choice is open to all mankind. On the other hand, it is a quietist and tolerant teaching, in that Egyptian Muslims are taught to welcome local Christians as members of the Egyptian nation, as people who share ancient cultural and national traditions, and to leave the judging of fellow Muslims to those who are charged with maintaining the religious heritage: the official religious establishment. ${ }^{19}$ Similar lessons of tolerance suffuse most other national curricula in the Middle East, as an international group of scholars led by Eleanor Doumato of the Watson Institute for International Affairs at Brown University has recently shown. ${ }^{20}$ Apart from a few troubling passages in the Saudi, Syrian and Iranian texts, incitements to violence are absent, and those they did discover were nearly always framed in defensive terms. One engages in violence and yearns for martyrdom only when one is under attack, not because God demands the slaying of non-Muslims. In any case, the evidence we have suggests that students are rarely motivated by schoolbook lessons - whether of tolerance and mercy or exclusion and violence. If this most quotidian observation of any classroom teacher is true, then why have American leaders become so interested in the contents of Middle Eastern curricula?

\section{WHAT IS EDUCATION FOR?}

Concerns about the cultural failures of Middle Eastern schooling highlight by implication three of the many different contemporary goals of education. Despite his bellicose tone, Toby Ziegler articulated an ideal of education as humanization, the development of enlightenment through liberal study. Knowing more means becoming more fully human. Donald Rumsfeld phrased the point of schooling as a balance between social control and political mobilization, while Colin Powell repeated clichés about global competitiveness that frame schooling as a macroeconomic strategy. While Ziegler's perspective derives from classical humanism, Rumsfeld and Powell outline postmodern ideals in which education becomes part of a global just-in-time inventory system. In the 1980s, we supported Pakistan's recruitment and training of Afghan mujahidin, which laid part of the groundwork for the extensive expansion of madrasas there. ${ }^{21}$ The U.S. Agency for International Development contracted with the Center for Afghanistan Studies at the University of Nebraska at Omaha to develop textbooks combining 
Islamic content with violently xenophobic military themes and pictures for distribution to schools in Afghanistan and refugee areas of Pakistan. These textbooks were intended to militarize youth and reinforce ideological opposition to the Soviet invasion in Islamic terms. Endlessly recirculated and then partially censored by the removal of human faces from the pictures, the books later formed the core of the Taliban school curriculum. ${ }^{22}$ Now, 20 years on, the jihadi product line is to be discontinued in favor of something else, perhaps Sufism. ${ }^{23}$ Postmodern theories of education, including the ideology of "life-long learning," are opposed to classical humanism in that they view humans not as perfectible individuals, but as units constantly to be trained and retrained to meet the changing needs of a global economy. Humanism - and this includes the traditions of religious training it informed and from which it descends shows us a fixed high goal of personal development. Postmodern education provides us with no goal except to chase endlessly the whims of global economic and ideological markets.

Although we have for decades expressed our ideas in terms of human rights rather than doctrinal purity, the assumptions we make about the way schooling works in the Middle East are similar to those the medieval Popes made about Talmudic education. These assumptions were, first, that parts of its content represent tendentious distortions of true - and therefore necessarily universal - religious doctrine. Second, that this distortion has been crafted by corrupt elders who wish to deny their children the truth and keep them entrapped in false consciousness. Third, that particular curricula create predictable sets of knowledge and motivation in students that reflect the intentions of their producers. And finally, that these curricula are the chief cause of some negative behavior.

Each of these assumptions is problematic. Whatever the intentions of the producers of these texts and whatever the truth value of their content, it is nearly impossible to attribute particular behaviors to textual bases. As Saif Dana has written with regard to Palestinian schools, for example, "Resistance [to Israel] stems from real living conditions, and not from ideas contained within the curriculum." ${ }^{24}$ Likewise, the evidence we have is that Mohammad Atta was radicalized not as an impressionable young man in Egypt, where he was presented with tolerant versions of Islam through high school and studied architecture at university, but in Germany, where he was a graduate student in urban planning. While investigating the curricula of German urban planning programs might be amusing, it would probably not lead to an explanation of why Atta and his companions slit the throats of stewardesses and rammed airplanes into skyscrapers.

People's motivations have very little to do with what they are told in school and much to do with their interactions with members of their families, their professional interests, their personal tragedies and the broader environment of experience. Sociologist David Reisman cautioned during the late 1940s against assuming

more than we....know about the consequences of reading one or another sort of book. There is always an element of indeterminacy in art; in the relation of a reader to a book many things — many unintended things can and do happen. ... [W]hat is a liberating book for one person may 
Middle East Policy, Vol. XIII, No. 1, Spring 2006

not be so for another - a point often overlooked by those who, nostalgically overestimating the uncorrupted tastes of an earlier day, assume that all those who read good books in the eighteenth century or saw Shakespeare's plays in Elizabethan days found the good things in them. ${ }^{25}$

This indeterminacy means that not only in terms of books, but also in terms of other socialization contexts, it is hard to pinpoint what will appeal to a particular child. Psychiatrist Anna Maria Rizzuto ${ }^{26}$ found that her patients' ideas about what God is like corresponded closely to their perceptions of their parents, an insight whose broader implications have been well understood for decades - if not centuries — by practical religious educators. ${ }^{27}$ It is not merely specific sorts of living conditions but networks of social support more generally that shape particular behaviors. As Yale anthropologist John Dollard pointed out in the midst of World War II,

The real controls of individual opinion are exercised by the intimate social group to which the individual belongs, and these cannot be blithely supplanted by mere mass propaganda....Prejudice is...in the social environment, which punishes us when we make any other than prejudiced responses....Against such massive processes one cannot work very effectively by the indirect means of books, radio or periodicals. What counts is the private behavior of the group members in intimate situations. As long as these social forces tend to reward anti-Semitic expressions and feelings, all other attempts to extirpate them are bound to be ineffectual. ${ }^{28}$

\section{PROXY WARS}

Exposure to violent media - the Bible's book of Joshua, chapter 8 of the Quran, or Mel Gibson's 2004 movie The Passion of the Christ — does not by itself motivate violence or prejudice. Even if school curricula did act as causal mechanisms, and even if we succeeded in revolutionizing school curricula throughout the Middle East, this would make little difference, since the militant texts that Atta read in Germany and later helped to produce in the United States were part of a vast underground literature. It is a literature that originates and thrives largely because it opposes and circulates outside the control of official institutions. Changing the school without changing the media, the Friday sermon at the mosque, the gossip of friendship circles, and the brutality of everyday life in regions of poverty, political oppression and war will do little to bring peace, Colin Powell to the contrary. The brutality and small-mindedness of the Taliban came not from the content of their education, but from its context: all-male institutions established in regions of exile and dispossession, cut off entirely from the normal flow of economic and family life which their young men would never know. ${ }^{29}$ If, in more normal circumstances, political leaders in the Middle East use schools as recruiting grounds for military units, this is not very different from the use to which American military recruiters put high schools, which are required by the No Child Left Behind Act to provide the military with contact information on their students. Muslim militant groups also use mosques for the same purposes of recruitment. As an American reporter recorded in the 1940s when asking famous bank robber Willie Sutton why he robbed 
banks, the answer was obvious: "Because that's where the money is." Schools (and mosques) are where the young men are.

Neither social nor political conflict are caused by one sort of training or another. Training is a response to instrumental needs rather than the cause of those needs. Conflict is caused by the social institutions, political and economic inequalities and opportunity structures that surround those training institutions and practices in the broader world. It's true that many children in the Middle East suffer from dreadfully poor educational opportunities, which we are called upon by our humanistic interests to improve. But from the perspective of either economic or national-security policy, what would be the point of teaching madrasa boys science, mathematics, literature and geography if these subjects have no real use in rural areas of desperately poor countries where entrenched elites have little interest in altering the status quo? Contrary to President Bush's claim in the 2004 presidential debates, education by itself does not create jobs.

Reform, according to Eleanor Doumato, is a value-laden concept. What is made better by reform is always relative to the interests of specific social groups. With respect to religious education specifically, the most important thing about school curricula may finally be not the effect they have on private belief, but the contribution they make in defining the terms of public debate. Changing them has to do with changing the political tactics of elites rather than the beliefs of the masses. Forcing change in curricula is merely a way to force elites to publicly articulate different ways of talking about conflict. This can be good and useful. But when such change happens due to outside pressure, it happens because curricula are a relatively easy thing to envision changing. Rewriting books is easier than changing fundamental social, economic and political institutions with powerful constituencies. Not all elites will be satisfied with these new ways of talking, though, because curriculum reform without the reform of infrastructure, political participation and economic opportunity will do nothing to stem internal and external conflicts that do far more than schools to create violent motivations. The doomed economy of petroleum, the patriarchal authority structures of rural villages, the brutality of the Saudi religious police, the legal persecution of Egyptian homosexuals, the abuse of Iraqi prisoners by American soldiers, targeted assassinations by Algerian paramilitaries or by Israeli pilots in American helicopters (not to mention Israeli soldiers driving American bulldozers) have far more influence over the political consciousness of children and youth than does anything taught in school, religious or otherwise.

Which brings me, finally, to another historical analogy with contemporary resonance. The biblical story of Eleazar and the elephant from First Maccabees, chapter 6 , was retold by Josephus in the first chapter of The Jewish War. In 162 $\mathrm{BCE}$, as Judah Maccabee was confronting 
Middle East Policy, Vol. XIII, No. 1, Spring 2006

the armies of the Seleucid king Antiochus V, Judah's younger brother Eleazar spotted one of the king's largest war elephants bearing royal armor. Believing it was the mount of the king himself, he decided to make his reputation by bringing the animal down and thereby ending the conflict. Eleazar ducked underneath the beast and thrust his weapon into its belly. The elephant collapsed and crushed Eleazar to death underneath it. The overwhelmed Maccabbean armies retreated, and the Greek forces did not withdraw until an internal Seleucid power struggle forced the king's absence.

There are lessons for us here today. King Antiochus was not, in fact, riding that particular elephant, and Eleazar's attack did nothing except earn him everlasting fame for having chosen the wrong target and the wrong approach. For it was not the elephant who killed Eleazar. Eleazar was killed by the hopeful foolhardiness of his own attack. Just as the elephant itself was not the cause of the war, textbooks are not a primary cause of conflict. They do not directly motivate violence or, by themselves, cause discriminatory predispositions or actions. Texts may be causes of conflict in the sense that people get mad about being insulted in other people's books. But attacking the content of curricula and pressuring change in them provides local intellectuals and would-be leaders with a powerful complaint with which to rally their constituents, as intellectuals and jurists in Jordan and Saudi Arabia did in early January 2004, when those countries announced U.S.-pressured textbook reforms. Exerting too heavy a hand in the development of Middle Eastern curricula, not to mention stepping into the middle of contemporary debates about the public role of Islam in Muslim countries through public diplomacy efforts ${ }^{30}$ can play into the hands of radicals whose arguments about the illegitimacy of their own governments are strengthened by the specter of foreign influence over what their children read and hear. Particularly in the context of the American invasion of Iraq, President Bush's support for Ariel Sharon's unilateralism, and the long series of clumsy American dealings with Iran, Pakistan, Afghanistan and other countries in the Middle East and Asia, our attempts at pressuring school reform begin to look less like an honest attempt to improve educational process, and more like an attempt to hijack foreign school curricula for our own narrow benefit. In effect, it is fighting a proxy war with Saudi Arabia in the schools of Yemen, Egypt, Pakistan and Morocco.

School experiences are linked in extremely complex ways with cultural maintenance and change. The unpleasant content of distasteful curricula will change when the unpleasant institutions in whose midst they are written change, at their own pace and, like the Seleucid withdrawal from Judea, for reasons of their own. The sad thing is that Eleazar never had the opportunity to learn that the king wasn't riding that particular elephant. Perhaps we can.

\footnotetext{
${ }^{1}$ Richard C. Lewontin, “The Politics of Science,” New York Review of Books, Vol.49, No.8 ( May 9, 2002), p. 31.

${ }^{2}$ Jeffrey Goldberg, "The Education of a Holy Warrior," The New York Times Magazine, June 25, 2000, pp. 32-64.

${ }^{3}$ Jeffrey Goldberg, "The Never-Ending Jihad,” Rolling Stone, October 25, 2001.

${ }^{4}$ Peter Bergen and Swati Pandey, "The Madrassa Myth," The New York Times, June 14, 2005.

${ }^{5}$ Mark Cohen, Under Crescent and Cross: The Jews in the Middle Ages. (Princeton University Press. 1994),
} 
p. 39; and Solomon Grayzell, The Church and the Jews in the XIIIth Century (1198-1254). Revised Edition. (Hermon Press, 1966), p. 277.

${ }^{6}$ Grayzell, ibid. pp. 30, 251, 253.

${ }^{7}$ Judah Rosenthal, "The Talmud on Trial: The Disputation at Paris in the Year 1240," Jewish Quarterly Review, Vol. 47. 1956, p. 150.

${ }^{8}$ Solomon Grayzell, The Church and the Jews in the XIIIth Century. Volume II (1254-1314) (The Jewish Theological Seminary of America: Wayne State University Press, 1989), p. 319.

${ }^{9}$ Grayzell, ibid. 1966, p. 279n.

${ }^{10} \mathrm{Ibid}, 1966$, p. 33. 1989, p. 10.

${ }^{11}$ James Muldon, Popes, Lawyers, and Infidels: The Church and the Non-Christian World 1250-1550

(University of Pennsylvania Press, 1979), p. 30.

${ }^{12}$ Ibid. p. 45 and Benjamin Z. Kedar, "Canon Law and the Burning of the Talmud," Bulletin of Medieval Canon Law 9, pp. 79-82.

${ }^{13}$ Walter Pakter, Medieval Canon Law and the Jews (Ebelsbach: Verlag Rolf Gremer, 1988), p. 77.

${ }^{14}$ Rosenthal, op. cit. p. 61.

${ }^{15}$ Alfred Milner, England in Egypt (Macmillan \& Co., 1892,) p. 390.

${ }^{16}$ John Bowring, Report on Egypt and Candia (House of Commons Sessional Papers, vol. Xxi. 1840), p. 137.

${ }^{17}$ Milner, op. cit. p. 366.

${ }^{18}$ H. Cunynghame, "The Present State of Education in Egypt," Journal of the Royal Asiatic Society of Great Britain and Ireland, N.S., vol. 19. 1887, p. 232.

${ }^{19}$ Gregory Starrett, Putting Islam to Work: Education, Politics, and Religious Transformation in Egypt (University of California Press, 1998).

${ }^{20}$ Eleanour Doumato and Gregory Starrett, eds., Teaching Islam: Texbooks and Religion in the Middle East (Lynne Reinner Publishers, 2006).

${ }^{21}$ Ahmad Rashid, Taliban (Yale University Press, 2000).

${ }^{22}$ Joe Stephens and David B. Ottaway, "From U.S., the ABC's of Jihad: Violent Soviet-Era Textbooks Complicate Afghan Education Efforts," The Washington Post, March 23, 2002, p. A 01; and International Crisis Group, "Pakistan: Madrasas, Extremism, and the Military," Islamabad/Brussels, ICG Asia Report No. 36.

${ }^{23}$ David E. Kaplan, "Hearts, Minds, and Dollars," U.S. News and World Report, April 23, 2005.

${ }^{24}$ Seaif $\mathrm{Da} \mathrm{Na}$, "Religious Identity and the Representation of History," in Doumato and Starrett, op. cit.

${ }^{25}$ David Reisman, "Tootle': A Modern Cautionary Tale," in Margaret Mead and Martha Wolfenstein, eds., Childhood in Contemporary Cultures (University of Chicago Press, 1955), p. 238.

${ }^{26}$ Anna Maria Riuzzo, The Birth of the Living God (University of Chicago Press, 1979).

${ }^{25}$ Cynthia Pearl Maus, Teaching the Youth of the Church: A Manual on Methods of Teaching Graded, Elective and Uniform Lesson Courses to Intermediates, Seniors and Young People in the Church's School (Doubleday \& Company, Inc., 1929), p. 62.

${ }^{26}$ John Dollard, "The Acquisition of New Social Habits," in Ralph Linton, ed., The Science of Man in the world Crisis (Colombia University Press,1947), pp. 442-464.

${ }^{27}$ Rashid, op. cit., David Edwards, Before Taliban: Genealogies of the Afghan Jihad (University of California Press, 2000).

${ }^{28}$ Kaplan, op. cit. 